\title{
Basic parameters of the static stability, loads and strength of the vital parts of a bucket wheel excavator's slewing superstructure
}

\author{
Srđan M. BOŠNJAK ${ }^{\dagger 1}$, Nebojša B. GNJATOVIĆ ${ }^{1}$, Sreten D. SAVIĆEVIĆ ${ }^{2}$, \\ Milorad P. PANTELIĆ ${ }^{3}$, Ivan Lj. MILENOVIĆ ${ }^{1}$ \\ ( ${ }^{1}$ Faculty of Mechanical Engineering, University of Belgrade, Belgrade 11120, Serbia) \\ $\left({ }^{2}\right.$ Faculty of Mechanical Engineering, University of Montenegro, Podgorica 81000, Montenegro) \\ $\left({ }^{3}\right.$ Faculty of Technical Sciences, University of Kragujevac, Čačak 32000, Serbia) \\ †E-mail: sbosnjak@mas.bg.ac.rs
}

Received Feb. 20, 2015; Revision accepted May 22, 2015; Crosschecked Apr. 7, 2016

\begin{abstract}
Determining a bucket wheel excavator (BWE)'s slewing superstructure weight and its center of gravity (COG) is of extreme importance not only in the design phase, but also after the completion of the erection process and during the operation of the machine. This paper presents a critical comparative analysis of the basic parameters of the static stability of a BWE 1600 superstructure, with the parameters being obtained by both analytical and experimental procedures. The analysis shows that a relatively small difference in superstructure mass, obtained by calculation, leads to a relatively large unfavorable shifting of its COG, necessitating a significant increase in counterweight mass for balancing. A procedure for superstructure 3D model mass correction is presented based on results obtained by weighing after the completion of the erection process. The developed model provides enough accuracy to determine the superstructure's COG in the entire domain of the bucket wheel boom inclination angle, and enables accurate load analysis of the superstructure's vital parts. The importance of this analysis is reinforced by the finding that the procedure prescribed by standard DIN 22261-2 gives results which are not on the side of safety, as shown by an example of strength analysis of a bucket wheel boom stays' end eyes.
\end{abstract}

Key words: Bucket wheel excavator (BWE), Slewing superstructure, Parameters of the static stability, Loads, Strength http://dx.doi.org/10.1631/jzus.A1500037

CLC number: TD422

\section{Introduction}

Bucket wheel excavators (BWEs) form the backbone of open cast mining systems and largely determine their output. BWEs operate in very harsh conditions, being exposed to extreme dynamic and stochastic loads. Improvements have been made in the estimation of working loads (Czmochowski, 2008; Bošnjak et al., 2009b; 2012; Gottvald and Kala, 2012), calculation methods (Bošnjak et al., 2006; Gottvald, 2010; Rusiński et al., 2010b; 2012),

\footnotetext{
* Project supported by the Ministry of Education, Science and Technological Development of Serbia Funded Project (No. TR35006) (Di) ORCID: Srđan M. BOŠNJAK, http://orcid.org/0000-0002-6571-8836 (C) Zhejiang University and Springer-Verlag Berlin Heidelberg 2016
}

production technologies and monitoring of vital subsystems (Bartelmus, 2006; Rişteiu et al., 2006; Yin et al., 2007; 2008; Bartelmus and Zimorz, 2009). However, failures of structural elements (Bošnjak et al., 2009a; Rusiński et al., 2010a; Bošnjak and Zrnić, 2012) and mechanisms (Dudek et al., 2011; Savković et al., 2011) are almost inevitable during BWE operation.

The slewing superstructure of the BWE 1600 (Fig. 1), consists of two main substructures: the substructure (SuS) of the bucket wheel boom (BWB) with mast 1 and BWB stays (SuS1) (Fig. 2); the substructure of the counterweight boom (CWB) with a slewing platform, mast 2, and CWB stays ( $\mathrm{SuS} 2)$ (Fig. 3). Changing the BWB inclination angle $\left(\alpha_{\mathrm{BWB}}\right)$ is realized by means of two winches (Fig. 1). 


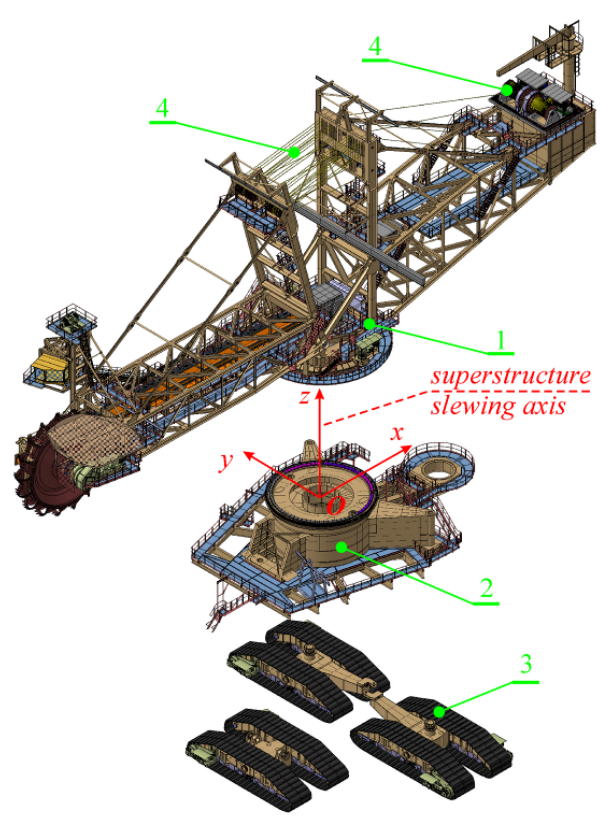

(a)

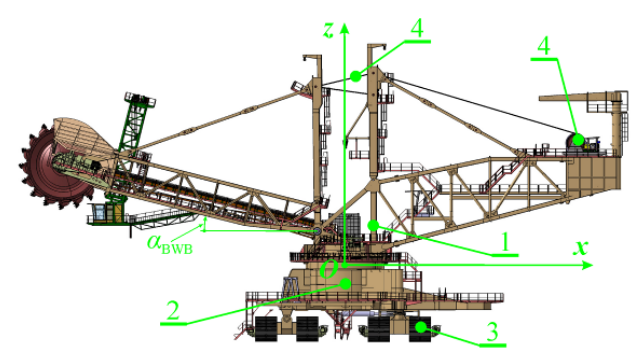

(b)

Fig. 1 Main parts of the BWE 1600 (a) and BWB inclination angle (b)

1: slewing superstructure; 2 : substructure; 3 : traveling mechanism; 4: winches for BWB positioning

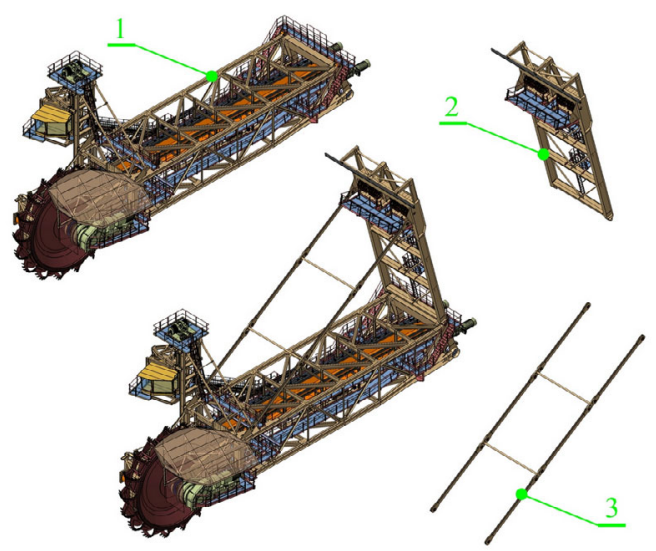

Fig. 2 Main parts of the SuS1 1: BWB; 2 : mast $1 ; 3$ : BWB stays

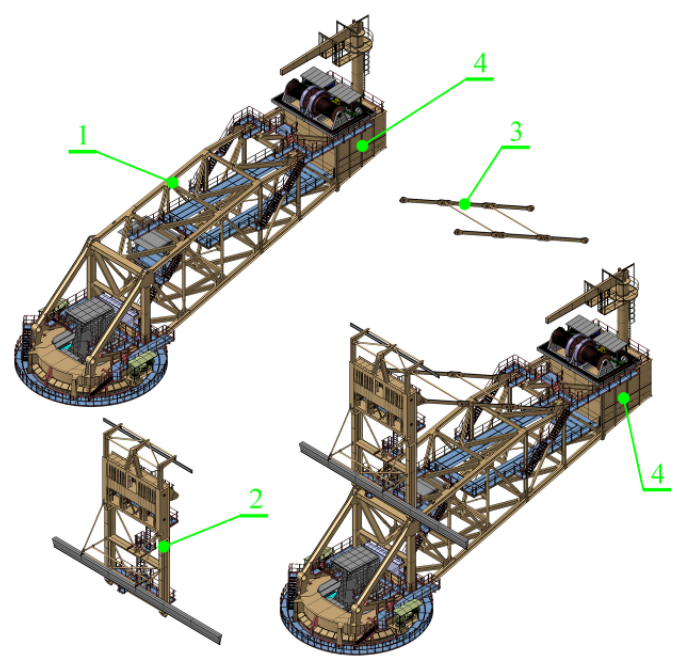

Fig. 3 Main parts of the SuS2

1: CWB with slewing platform; 2 : mast $2 ; 3$ : CWB stays; 4: counterweight $(\mathrm{CW})$ box

The slewing superstructure parameters largely determine the basic operation characteristics, reliability, and safety of a BWE. The parameters may be classified into three main groups: (a) those which determine the static stability of the superstructure; (b) those which determine the strength of the superstructure, and (c) those which determine the dynamic behavior of the superstructure. The common denominators of all these parameters are the mass of the superstructure and its distribution along the structure. That is why the basic parameters of static stability (BPSS), above all the weight and the position of the center of gravity (COG), must be carefully determined in all phases of BWE design. Even with world-renowned manufacturers, significant differences in these superstructure parameters appear during BWE design development, usually as a consequence of subsequent buyer requests, or the inability to purchase components predefined by the project. That is also why, after the first BWE erection, the weighing of the superstructure and determination of its COG position must be carried out to validate the design parameters (Durst and Vogt, 1988; Nan et al., 2008). Deviations in the superstructure's COG position in relation to its designed position need to be compensated by changing the $\mathrm{CW}$ mass.

This paper presents:

1. The results of analytical-numerical investigations of BPSS at various stages of BWE 1600 project 
development. These investigations were based on:

(1) The preliminary stability calculation provided by the BWE manufacturer (Variant 1, V1);

(2) The final stability calculation provided by the BWE manufacturer (Variant 2, V2);

(3) A 3D model of the BWE superstructure (Variant 3, V3) (Figs. 1-3);

(4) A 3D model of the BWE superstructure, with the mass corrected according to the results of the first weighing (Variant 4, V4);

(5) A final stability calculation, with the mass corrected according to the results of the first weighing (Variant 5, V5).

2. The results of the two weighings, made on site, after the first erection of the machine.

3 . The results of a strength analysis of the vital parts of the superstructure.

The results presented in this paper are important because the same or similar problems could arise in other surface mining machines such as spreaders, mobile conveyors, and draglines.

\section{Analytical determination of the BPSS: V1}

\section{vs. V2}

The final shaping of the carrying structure and its adjustment with the mechanical subsystems and equipment, i.e., transformation from V1 to V2, causes a change in the superstructure BPSS (Table 1, Figs. 4 and 5).

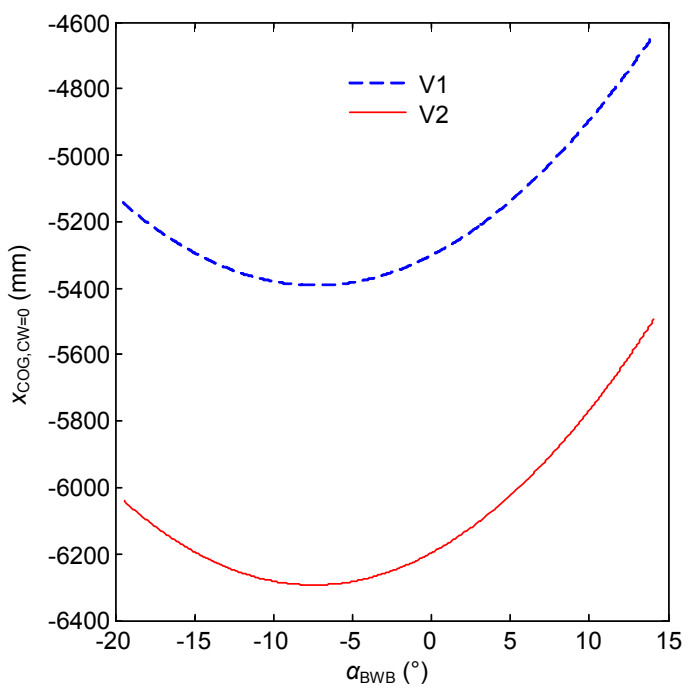

Fig. 4 COG abscissas of the superstructure without the $\mathrm{CW}$ mass $\left(x_{\mathrm{COG}, \mathrm{CW}=0}\right)$ : $\mathrm{V} 1$ vs. $\mathrm{V} 2$
Table 1 Mass of the superstructure and its substructures: V1 vs. V2

\begin{tabular}{cccc}
\hline \multirow{2}{*}{ Item } & \multicolumn{3}{c}{ Mass (t) } \\
\cline { 2 - 4 } & SuS1 & SuS2 & $\begin{array}{c}\text { Total without } \\
\text { CW mass }\end{array}$ \\
\hline V1 & 451.395 & 540.767 & 992.162 \\
V2 & 467.518 & 509.852 & 977.370 \\
\hline $\begin{array}{c}\text { Difference, } \\
\text { "V2-V1" }\end{array}$ & 16.123 & -30.915 & -14.792 \\
\hline
\end{tabular}

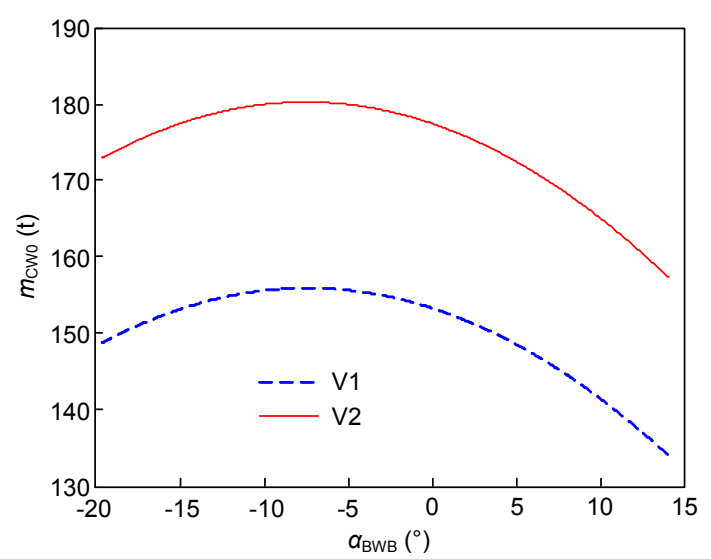

Fig. 5 Mass of the $\mathrm{CW}\left(m_{\mathrm{Cw} 0}\right)$ for balancing the superstructure deadweight: V1 vs. V2

\section{Discussion 1: V1 vs. V2}

The data presented in Table 1 show that a relatively small difference in superstructure mass between V1 and V2,

$$
\begin{aligned}
& \frac{m_{\mathrm{S}, \mathrm{CW}=0}^{\mathrm{V} 1}-m_{\mathrm{S}, \mathrm{CW}=0}^{\mathrm{V} 2}}{m_{\mathrm{S}, \mathrm{CW}=0}^{\mathrm{V}}} \times 100 \% \\
& =[(992.162-977.37) / 992.162] \times 100 \%=1.5 \%,
\end{aligned}
$$

leads to a very great difference in the abscissas of the $\mathrm{COG}$ for the superstructure without a $\mathrm{CW}$ mass $\left(x_{\mathrm{COG}, \mathrm{CW}=0}\right)$ (Figs. 4 and 6, Table 2). The absolute value of the minimal difference in the COG abscissas (Fig. 6),

$\left|\left(x_{\mathrm{COG}, \mathrm{CW}=0}^{\mathrm{V} 2}-x_{\mathrm{COG}, \mathrm{CW}=0}^{\mathrm{V} 1}\right)_{\min }\right|=|-902| \mathrm{mm}=902 \mathrm{~mm}$,

represents the maximum difference between the considered abscissas.

The unfavorable shifting of the COG towards the bucket wheel is a consequence of the unfavorable 
distribution of the superstructure deadweight for V2. Namely, for V2, the mass of SuS1 is $16.123 \mathrm{t}$ greater and the mass of $\mathrm{SuS} 2$ is $30.915 \mathrm{t}$ smaller. For this reason, the V2 superstructure needs a considerably greater $\mathrm{CW}$ mass to balance its deadweight $\left(m_{\mathrm{CW} 0}\right)$ (Figs. 5 and 7, Table 2), which increases the total $\mathrm{CW}$ mass from $m_{\mathrm{CW}}^{\mathrm{V} 1}=197 \mathrm{t}$ for $\mathrm{V} 1$ to $m_{\mathrm{CW}}^{\mathrm{V} 2}=221 \mathrm{t}$ for V2 to sustain the projected COG abscissas of the superstructure with $\mathrm{CW}$ mass (Fig. 8, Table 3).

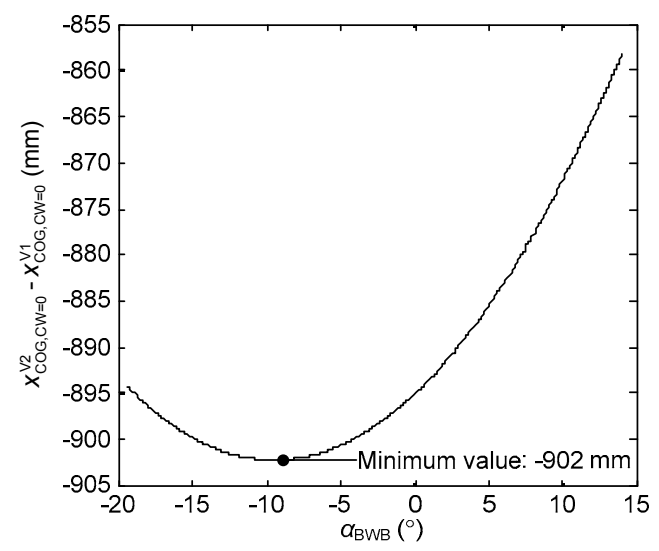

Fig. 6 Difference between the COG abscissas of the superstructures without a $\mathrm{CW}$ mass: $\mathrm{V} 1$ vs. $\mathrm{V} 2$

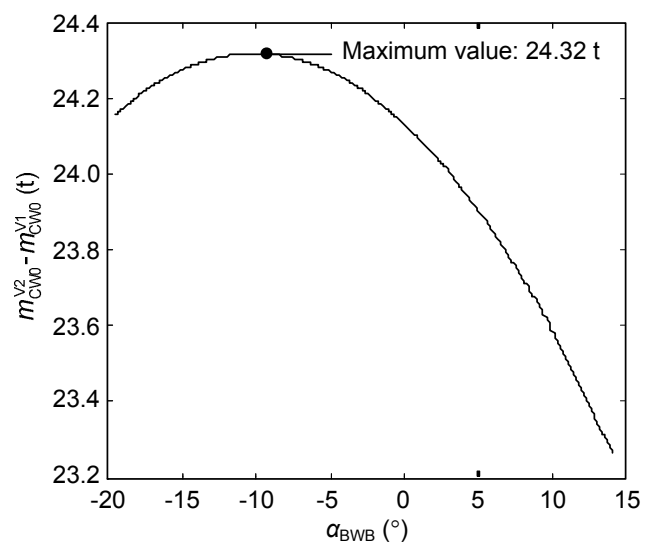

Fig. 7 Difference between the masses of the $\mathrm{CW}$ for balancing the superstructure deadweight: V1 vs. V2

\section{Analytical determination of the BPSS of the superstructure 3D model: V3}

The 3D model of the superstructure (Figs. 1-3) enables a very precise determination of the weight and COG position of all structural and mechanical parts that are incorporated in the 3D model with their real shape, dimensions, and masses (Table 4, Figs. 9 and 10).

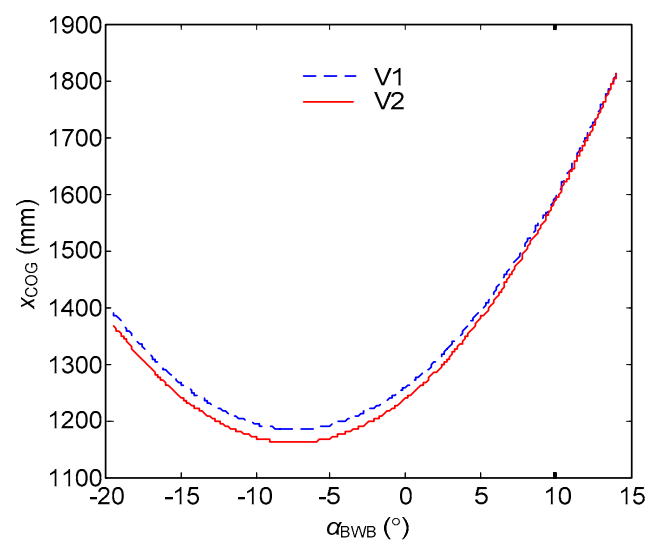

Fig. 8 Projected COG abscissas $\left(x_{\mathrm{COG}}\right)$ of the superstructures with a CW mass: V1 vs. V2

Table 3 Projected COG abscissas of the superstructures with a CW mass: V1 vs. V2

\begin{tabular}{lccc}
\hline \multirow{2}{*}{ BWB position } & \multicolumn{3}{c}{$x_{\mathrm{COG}}(\mathrm{mm})$} \\
\cline { 2 - 4 } & $\mathrm{V} 1$ & $\mathrm{~V} 2$ & "V2-V1" \\
\hline $\mathrm{L}: \alpha_{\mathrm{BWB}}=-19.5^{\circ}$ & 1392 & 1370 & -22 \\
$\mathrm{H}$ & 1258 & 1238 & -20 \\
$\mathrm{Hi}: \alpha_{\mathrm{BWB}}=14.1^{\circ}$ & 1814 & 1812 & -2 \\
\hline
\end{tabular}

Table 4 Mass of the superstructure and its substructures according to the 3D model: $\mathrm{V3}$

\begin{tabular}{cccc}
\hline \multirow{2}{*}{ Item } & \multicolumn{3}{c}{ Mass $(\mathrm{t})$} \\
\cline { 2 - 4 } & SuS1 & SuS2 & $\begin{array}{c}\text { Total without } \\
\text { CW mass }\end{array}$ \\
\hline V3 & 476.119 & 502.147 & 978.266 \\
\hline
\end{tabular}

Table 2 COG abscissas of the superstructures without a $\mathrm{CW}$ mass $\left(x_{\mathrm{COG}, \mathrm{CW}=0}\right)$ and $\mathrm{CW}$ masses for balancing the superstructure deadweight $\left(m_{\mathrm{Cw0}}\right)$ : V1 vs. V2

\begin{tabular}{|c|c|c|c|c|c|c|}
\hline \multirow{2}{*}{ BWB position } & \multicolumn{3}{|c|}{$x_{\mathrm{COG}, \mathrm{CW}=0}(\mathrm{~mm})$} & \multicolumn{3}{|c|}{$m_{\mathrm{CW} 0}(\mathrm{t})$} \\
\hline & V1 & V2 & "V2-V1" & V1 & V2 & "V2-V1" \\
\hline $\mathrm{L}^{\mathrm{a}}: \alpha_{\mathrm{BWB}}=-19.5^{\circ}$ & -5142 & -6036 & -894 & 148.7 & 172.9 & 24.15 \\
\hline $\mathrm{H}^{\mathrm{b}}$ & -5303 & -6198 & -895 & 153.4 & 177.5 & 24.13 \\
\hline $\mathrm{Hi}^{\mathrm{c}}: \alpha_{\mathrm{BWB}}=14.1^{\circ}$ & -4636 & -5494 & -858 & 134.1 & 157.4 & 23.26 \\
\hline
\end{tabular}

${ }^{\mathrm{a}}$ Low; ${ }^{\mathrm{b}}$ Horizontal; ${ }^{\mathrm{c}}$ High 


\section{Weighing the superstructure}

The superstructure was weighed on site immediately after the first erection of the machine (Figs. 11-13, Table 5). During the first weighing (W1), the CW mass was $177.017 \mathrm{t}$, which was supposed to be enough to balance the superstructure deadweight according to V2. After the first erection,

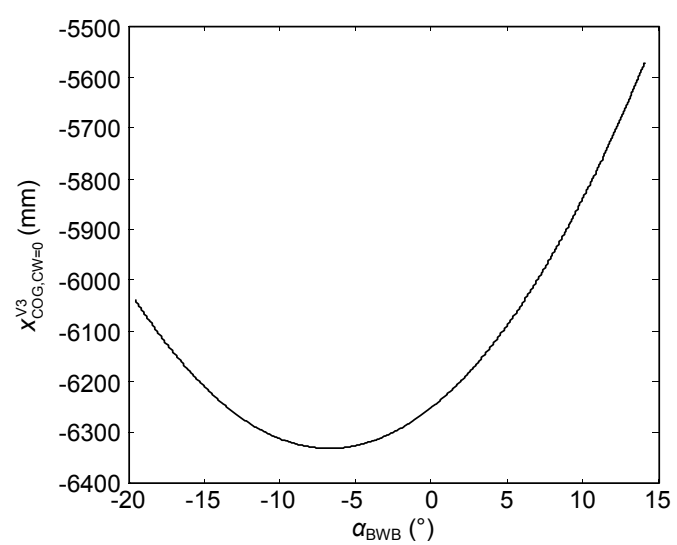

Fig. 9 COG abscissas of the superstructure without a CW mass: $\mathrm{V} 3$

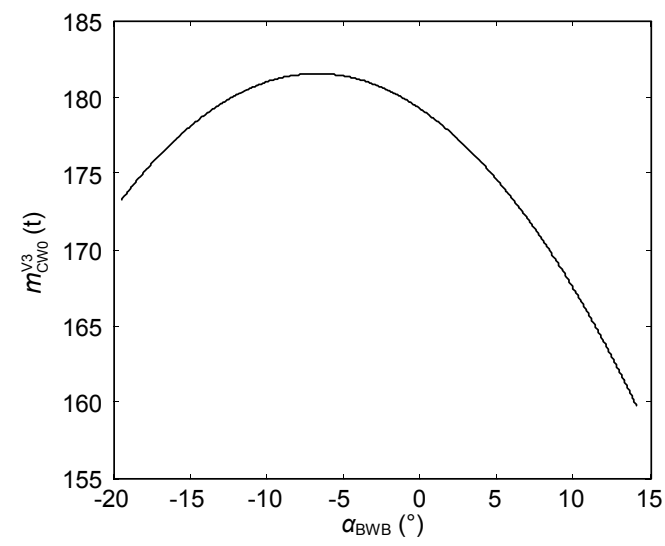

Fig. 10 Mass of the $\mathrm{CW}$ for balancing the superstructure deadweight: V3 the $\mathrm{CW}$ mass was corrected (54.960 $\mathrm{t}$ added), so the $\mathrm{CW}$ mass during the second weighing (W2) was 231.977 t. Moreover, during the second weighing, the superstructure was loaded with foreign bodies (1.24 t) and a little bit of snow (Fig. 14).

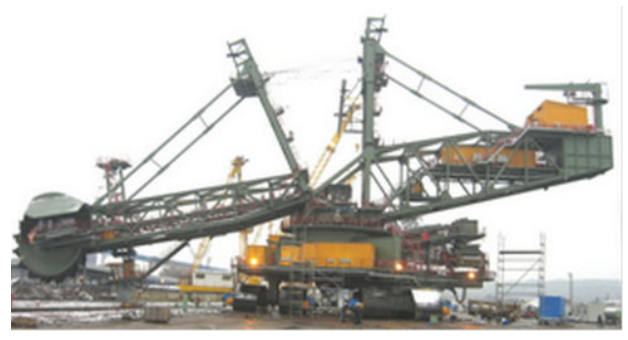

Fig. 11 BWE during the first weighing on the erection site

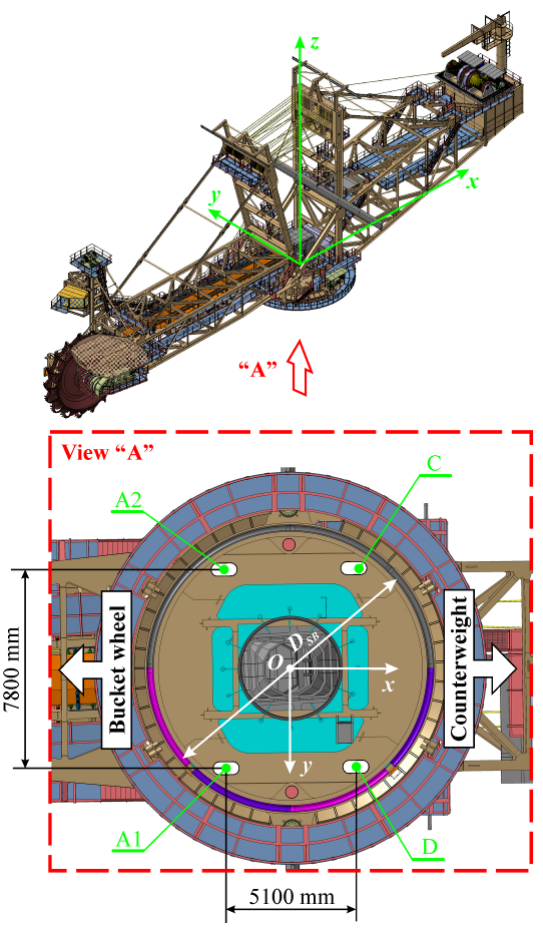

Fig. 12 Layout of the measuring points (diameter of the slew bearing, $D_{\mathrm{SB}}=11000 \mathrm{~mm}$ )

Table 5 Results of the superstructure weighing

\begin{tabular}{|c|c|c|c|c|c|c|c|}
\hline \multirow{2}{*}{ Weighing } & \multicolumn{4}{|c|}{ Support reaction at measuring points $(\mathrm{kN})$} & \multirow{2}{*}{$\begin{array}{l}\text { Weight of the } \mathrm{S}^{\mathrm{c}} \text {, } \\
\qquad G_{\mathrm{S}}(\mathrm{kN})\end{array}$} & \multicolumn{2}{|c|}{ Coordinate of the COG $(\mathrm{mm})$} \\
\hline & $R_{\mathrm{A} 1}$ & $R_{\mathrm{A} 2}$ & $R_{\mathrm{B}}$ & $R_{\mathrm{C}}$ & & $x_{\mathrm{COG}}$ & $y_{\mathrm{COG}}$ \\
\hline \multicolumn{8}{|l|}{$\overline{W 1^{\mathrm{a}}: \mathrm{BWB} \text { position }}$} \\
\hline $\mathrm{L}: \alpha_{\mathrm{BWB}}=-12.9^{\circ}$ & 3259.4 & 3307.8 & 2312.1 & 2620.0 & 11499.2 & -398 & -121 \\
\hline $\mathrm{H}$ & 3260.4 & 3221.9 & 2305.3 & 2713.7 & 11501.1 & -356 & -125 \\
\hline Hi: $\alpha_{\mathrm{BWB}}=14.1^{\circ}$ & 2608.9 & 2630.5 & 2967.4 & 3292.6 & 11499.4 & 249 & -118 \\
\hline \multicolumn{8}{|l|}{$\mathrm{W} 2^{\mathrm{b}}$ : BWB position } \\
\hline $\mathrm{L}: \alpha_{\mathrm{BWB}}=-11.4^{\circ}$ & 1808.5 & 1893.1 & 4040.6 & 4361.0 & 12103.3 & 1087 & -130 \\
\hline
\end{tabular}

${ }^{\mathrm{a}} \mathrm{CW}$ mass: $177.017 \mathrm{t} ;{ }^{\mathrm{b}} \mathrm{CW}$ mass: $231.977 \mathrm{t} ;{ }^{\mathrm{c}}$ Superstructure 


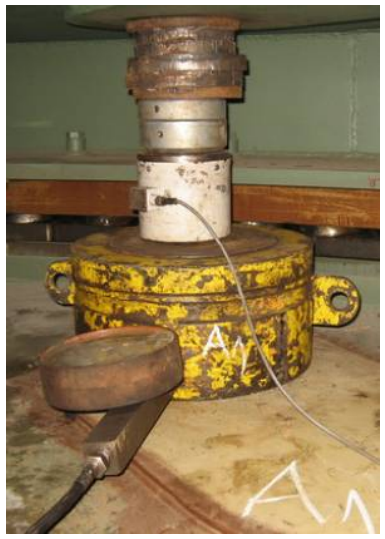

(a)

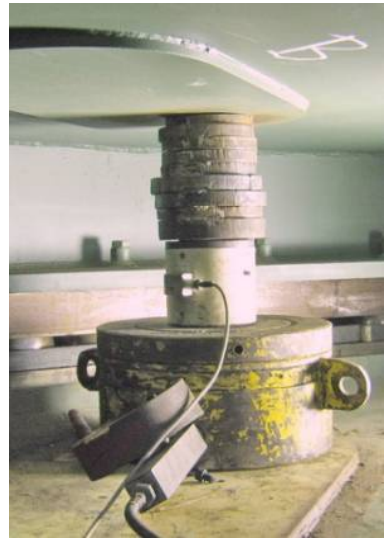

(c)

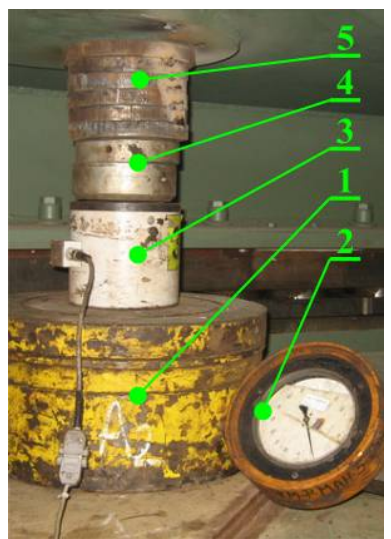

(b)

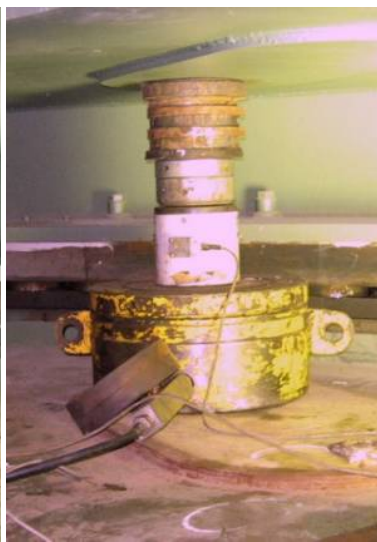

(d)
Fig. 13 Measuring points (1: hydro cylinder; 2: manometer; 3: load cell; 4: calotte; 5: compensation plates): (a) measuring point $A_{1}$; (b) measuring point $A_{2}$; (c) measuring point $B$; (d) measuring point $C$

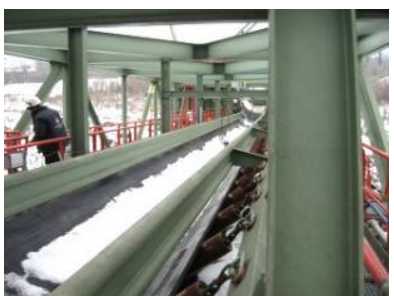

(a)

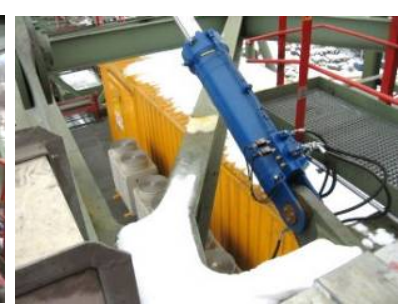

(b)
Fig. 14 Level of snow during the second weighing: (a) bucket wheel boom; (b) counterweight boom

\section{Correction of the mass of the superstruc- ture models based on the results of the first weighing}

According to the results of the first weighing (Table 5) the average superstructure mass is

$$
\begin{aligned}
& m_{\mathrm{S}, \mathrm{W} 1, \mathrm{~A}}=\frac{1}{3 g} \sum_{p=1}^{3} G_{\mathrm{S}, p} \\
& =[(11499.2+11501.1+11499.4) /(3 \times 9.81)] \times 10^{3} \mathrm{~kg} \\
& =1172.263 \times 10^{3} \mathrm{~kg}=1172.263 \mathrm{t},
\end{aligned}
$$

where $g$ represents the acceleration of gravity, while the mass of the 3D model superstructure (V3, Table 4) with a $\mathrm{CW}$ of $m_{\mathrm{CW} 1}=177.017 \mathrm{t}$ (CW mass during the first weighing) is

$$
\begin{aligned}
m_{\mathrm{S}, \mathrm{CW} 1}^{\mathrm{V} 3} & =m_{\mathrm{S}, \mathrm{CW}=0}^{\mathrm{V} 3}+m_{\mathrm{CW} 1}=(978.266+177.017) \mathrm{t} \\
& =1155.283 \mathrm{t} .
\end{aligned}
$$

Thus, the experimentally determined superstructure mass is greater by

$$
\begin{aligned}
\Delta m_{\mathrm{S}}^{\mathrm{V} 3} & =m_{\mathrm{S}, \mathrm{W} 1, \mathrm{~A}}-m_{\mathrm{S}, \mathrm{CW} 1}^{\mathrm{V} 3} \\
& =(1172.263-1155.283) \mathrm{t}=16.980 \mathrm{t}
\end{aligned}
$$

than the superstructure 3D model mass.

The COG abscissas of the superstructure 3D model with a CW mass of $m_{\mathrm{CW} 1}=177.017 \mathrm{t}$ are presented in Table 6. Because the superstructure COG based on the weighing results is shifted towards the bucket wheel (BW) (Tables 5 and 6), the excessive mass $\Delta m_{\mathrm{S}}^{\mathrm{V} 3}$ (the so-called 'corrective mass' from Eq. (5)) is on the BWB side. The abscissas of its center (point $\mathrm{C}$ in Fig. 15) for characteristic positions of the BWB (low, index "L"; horizontal, index "H"; high, index "Hi") are determined by the expressions:

$$
\begin{aligned}
x_{\mathrm{C}, \mathrm{L}}= & \frac{G_{\mathrm{S}, \mathrm{L}}^{\mathrm{W} 1} x_{\mathrm{COG}, \mathrm{L}}^{\mathrm{W} 1}-m_{\mathrm{S}, \mathrm{CW} 1}^{\mathrm{V} 3} g x_{\mathrm{COG}, \mathrm{L}}^{\mathrm{V} 3}}{\Delta m_{\mathrm{S}}^{\mathrm{V} 3} g}=\left\{\left[11499.2 \times 10^{3}\right.\right. \\
& \times\left(-398 \times 10^{-3}\right)-1155.283 \times 9.81 \times 10^{3} \\
& \left.\left.\times\left(-75 \times 10^{-3}\right)\right] /\left(16.98 \times 10^{3} \times 9.81\right)\right\} \mathrm{m} \\
& =-22.373 \mathrm{~m}, \\
x_{\mathrm{C}, \mathrm{H}} & =\frac{G_{\mathrm{S}, \mathrm{H}}^{\mathrm{W} 1} x_{\mathrm{COG}, \mathrm{H}}^{\mathrm{W} 1}-m_{\mathrm{S}, \mathrm{CW} 1}^{\mathrm{V} 3} g x_{\mathrm{COG}, \mathrm{H}}^{\mathrm{V} 3}}{\Delta m_{\mathrm{S}}^{\mathrm{V} 3} g}=\left\{\left[11501.1 \times 10^{3}\right.\right. \\
& \times\left(-356 \times 10^{-3}\right)-1155.283 \times 9.81 \times 10^{3} \\
& \left.\left.\times\left(-66 \times 10^{-3}\right)\right] /\left(16.98 \times 10^{3} \times 9.81\right)\right\} \mathrm{m} \\
& =-20.090 \mathrm{~m}, \\
& =\frac{G_{\mathrm{S}, \mathrm{Hi}}^{\mathrm{W} 1} x_{\mathrm{COG}, \mathrm{Hi}}^{\mathrm{W} 1}-m_{\mathrm{S}, \mathrm{CW} 1}^{\mathrm{V} 3} g x_{\mathrm{COG}, \mathrm{Hi}}^{\mathrm{V} 3}}{\Delta m_{\mathrm{S}}^{\mathrm{V} 3} g}=\left\{\left[11499.4 \times 10^{3}\right.\right. \\
x_{\mathrm{C}, \mathrm{Hi}} & \left.\times 249 \times 10^{-3}-1155.283 \times 9.81 \times 10^{3} \times 509 \times 10^{-3}\right] \\
& \left./\left(16.98 \times 10^{3} \times 9.81\right)\right\} \mathrm{m}=-17.442 \mathrm{~m} .
\end{aligned}
$$


Table 6 Projected COG abscissas of the superstructure 3D model (V3) with $m_{\mathrm{CW1}}=177.017 \mathrm{t}$

\begin{tabular}{lc}
\hline \multicolumn{1}{c}{ BWB position } & $x_{\mathrm{COG}}(\mathrm{mm})$ \\
\hline $\mathrm{L}: \alpha_{\mathrm{BWB}}=-12.9^{\circ}$ & -75 \\
$\mathrm{H}$ & -66 \\
$\mathrm{Hi}: \alpha_{\mathrm{BWB}}=14.1^{\circ}$ & 509 \\
\hline
\end{tabular}

The abscissa of the corrective mass center, relative to the moving coordinate system $O_{1} \xi \eta \zeta$ attached to the BWB (Fig. 15), is determined by the following expression:

$$
\xi_{\mathrm{C}}=a_{\mathrm{C}}=-x_{\mathrm{C}, \mathrm{H}}-c=-(-20.09)-3.878=16.212 \mathrm{~m}
$$

where $a_{\mathrm{C}}$ and $c$ are shown in Fig. 15.

Applicates of the corrective mass center in low and high BWB positions (Fig. 15) are determined by the expressions:

$$
\begin{aligned}
\zeta_{\mathrm{C}, \mathrm{L}} & =-b_{\mathrm{C}, \mathrm{L}}=-\left(x_{\mathrm{C}, \mathrm{L}}+c+\xi_{\mathrm{C}} \cos \alpha_{\mathrm{BWB}, \mathrm{L}}\right) / \sin \alpha_{\mathrm{BWB}, \mathrm{L}} \\
& =-\left\{\left[-22.373+3.878+16.212 \cos \left(-12.9^{\circ}\right)\right]\right. \\
& \left./ \sin \left(-12.9^{\circ}\right)\right\} \mathrm{m}=-12.059 \mathrm{~m}, \\
\zeta_{\mathrm{C}, \mathrm{Hi}} & =-b_{\mathrm{C}, \mathrm{Hi}}=-\left(x_{\mathrm{C}, \mathrm{Hi}}+c+\xi_{\mathrm{C}} \cos \alpha_{\mathrm{BWB}, \mathrm{Hi}}\right) / \sin \alpha_{\mathrm{BWB}, \mathrm{Hi}} \\
& =-\left\{\left[-17.442+3.878+16.212 \cos \left(14.1^{\circ}\right)\right]\right. \\
& \left./ \sin \left(14.1^{\circ}\right)\right\} \mathrm{m}=-8.865 \mathrm{~m} .
\end{aligned}
$$

To obtain a model which gives good approximations of the COG abscissas in both the low and high BWB positions simultaneously, the applicate of the center of the corrective mass is determined by the expression:

$$
\zeta_{\mathrm{C}}=k\left(\zeta_{\mathrm{C}, \mathrm{L}}+\zeta_{\mathrm{C}, \mathrm{Hi}}\right)
$$

where $k$ is the corrective factor. The influence of the $k$ factor value on the difference between the superstructure COG abscissas obtained experimentally and by calculation $\left(\Delta x_{\mathrm{COG}}=x_{\mathrm{COG}}^{\mathrm{W} 1}-x_{\mathrm{COG}}^{\mathrm{V} 3}\right)$ for the characteristic BWB positions is shown in Fig. 16.

In the horizontal BWB position, the applicate of the corrective mass center does not affect the superstructure COG abscissa. Therefore, the difference between the abscissas $\Delta x_{\mathrm{COG}, \mathrm{H}}$ (solid line in Fig. 16) is not influenced by variation in the value of coefficient $k$. Lines representing the dependence of

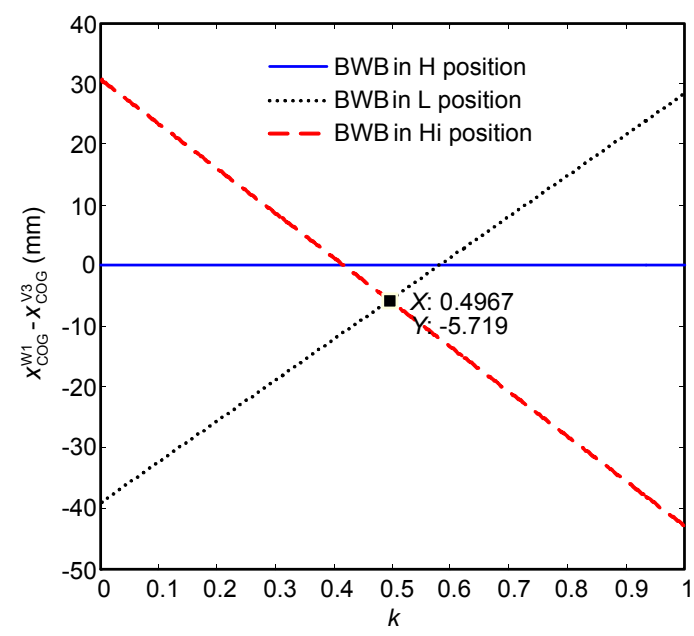

Fig. 16 Deviation of the COG abscissa

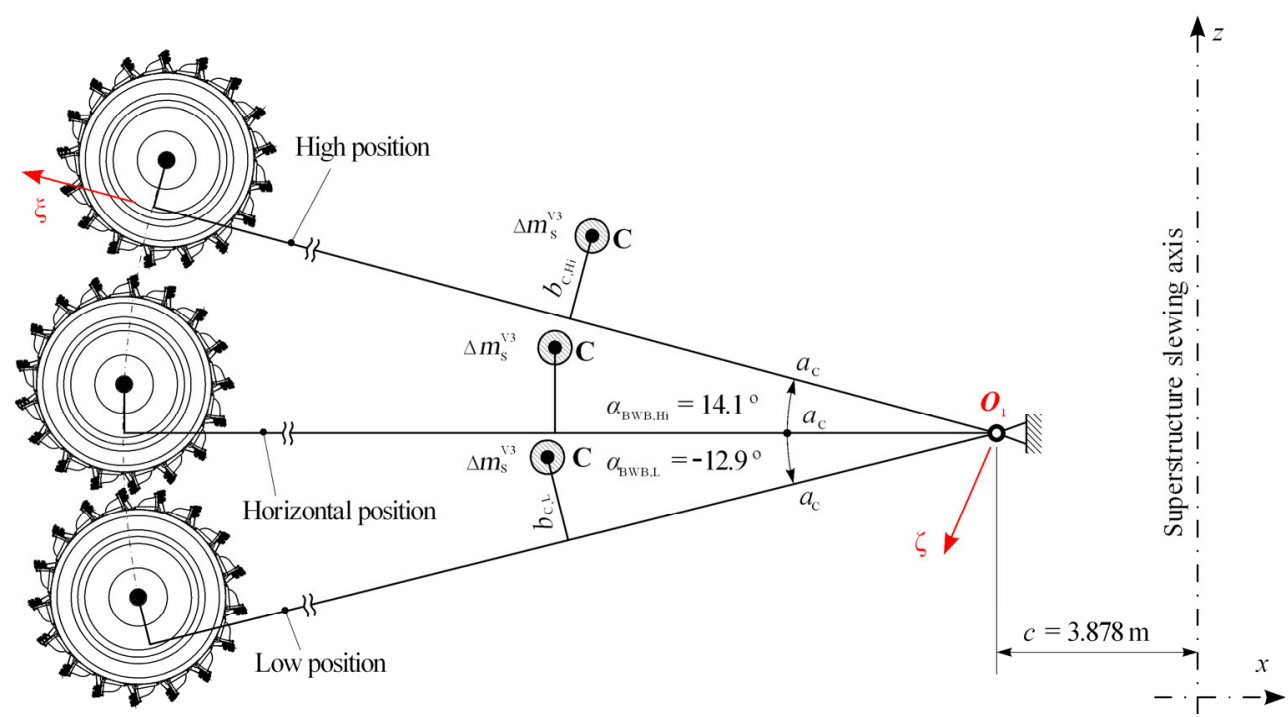

Fig. 15 Determination of the corrective mass center position 
$\Delta x_{\mathrm{COG}, \mathrm{Hi}}$ (dash line in Fig. 16) and $\Delta x_{\mathrm{COG}, \mathrm{L}}$ (dot line in Fig. 16) on the value of the corrective factor $k$ intersect at a point with an abscissa value of $k=0.4967$. For that value of the corrective factor $k$, the absolute values of deviations in the COG abscissas, in relation to the abscissas determined using the first weighing results, are smaller than $6 \mathrm{~mm}$. Adopting $k=0.5$, the corrective mass for V2 was determined analogously.

By introducing the corrective mass determined in this way, V3 is transformed into V4, while V2 is transformed into V5.

\section{Discussion 2: comparative analysis of an- alytical and experimental results}

The basic parameters of the superstructure with a CW of $m_{\mathrm{CW} 1}=177.017 \mathrm{t}$ are presented in Figs. 1720 and Table 7. Based on the presented results, V4 gives the best approximation of the superstructure COG abscissa in relation to the first weighing results (Fig. 17, Table 7). Nevertheless, it is important to note that the intensities of the winch rope forces, and of the BWB stay forces, are the highest specifically for V4 (Figs. 19 and 20). This is a consequence of the less favorable final deadweight distribution with respect to V1, which was the basic BWE design (Tables 7 and 8). Otherwise, the V4 results are in good agreement with the second weighing results (Fig. 21) and, therefore, V4 was adopted for further analyses and determination of the stress states of the vital superstructure parts.

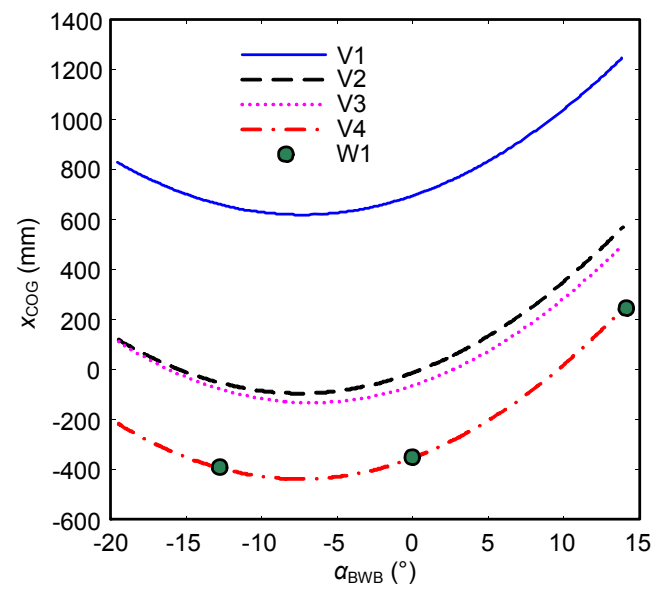

Fig. 17 Abscissas of the superstructure COG

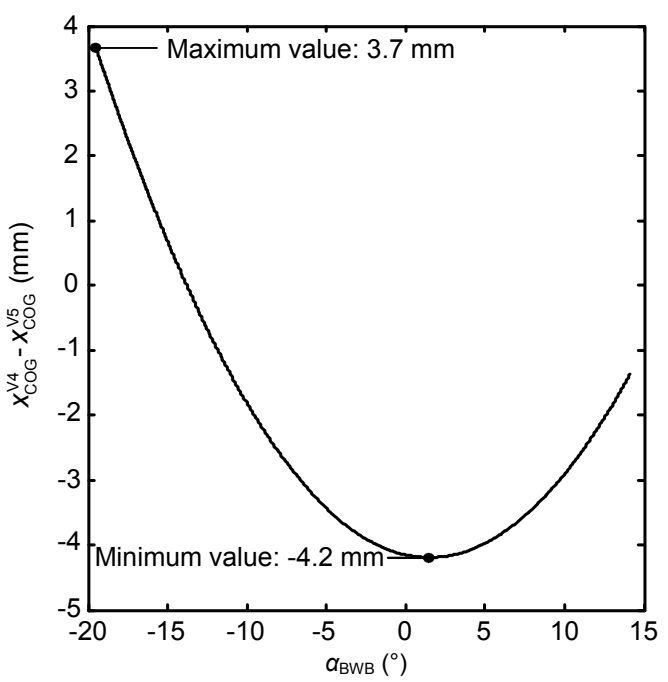

Fig. 18 Difference in the COG abscissas for V4 and V5

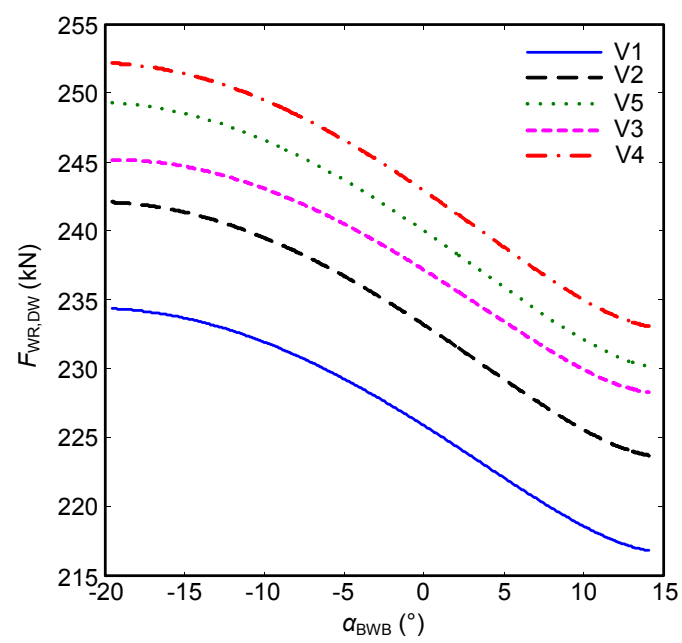

Fig. 19 Winch rope forces caused by deadweight

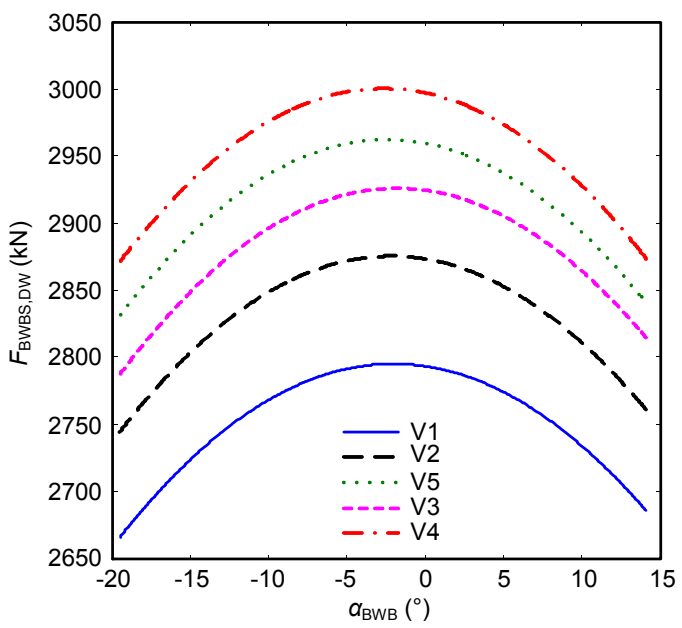

Fig. 20 BWB stay forces caused by deadweight 
Table 7 BPSS, winch rope force, and force in BWB stay

\begin{tabular}{|c|c|c|c|c|c|c|c|c|c|c|c|c|c|}
\hline \multirow{4}{*}{ Variant } & \multirow{4}{*}{$\begin{array}{l}\text { Total } \\
\text { mass } \\
(\mathrm{t})\end{array}$} & \multirow{4}{*}{$\begin{array}{c}\mathrm{CW} \\
\operatorname{mass}(\mathrm{t})\end{array}$} & \multirow{4}{*}{$\begin{array}{l}\text { Total mass } \\
\text { without } \\
\text { CW mass } \\
\text { (t) }\end{array}$} & \multicolumn{4}{|c|}{$\begin{array}{c}\text { Abscissa of COG, } \\
x_{\mathrm{COG}}(\mathrm{mm})\end{array}$} & \multicolumn{3}{|c|}{$\begin{array}{c}\text { Winch rope force } \\
\text { caused by deadweight, } \\
F_{\text {WR,DW }}(\mathrm{kN})\end{array}$} & \multicolumn{3}{|c|}{$\begin{array}{c}\text { BWB stay force } \\
\text { caused by deadweight, } \\
F_{\text {BWBS,DW }}(\mathrm{kN})\end{array}$} \\
\hline & & & & L: & $\mathrm{L}$ & & Hi: & L: & & $\mathrm{Hi}:$ & $\mathrm{L}:$ & & Hi: \\
\hline & & & & $\alpha_{\mathrm{BWB}}=$ & $\alpha_{\mathrm{BWB}}=$ & $\mathrm{H}$ & $\alpha_{\mathrm{BWB}}=$ & $\alpha_{\mathrm{BWB}}=$ & $\mathrm{H}$ & $\alpha_{\mathrm{BWB}}=$ & $\alpha_{\mathrm{BWB}}=$ & $\mathrm{H}$ & $\alpha_{\mathrm{BWB}}=$ \\
\hline & & & & $-19.5^{\circ}$ & $-12.9^{\circ}$ & & $14.1^{\circ}$ & $-19.5^{\circ}$ & & $14.1^{\circ}$ & $-19.5^{\circ}$ & & $14.1^{\circ}$ \\
\hline V1 & 1169.179 & 177.017 & 992.162 & 829 & 663 & 693 & 1259 & 234.3 & 225.9 & 216.8 & 2666 & 2794 & 2686 \\
\hline V2 & 1154.387 & 177.017 & 977.370 & 122 & -51 & -15 & 581 & 242.1 & 233.2 & 223.7 & 2744 & 2874 & 2760 \\
\hline V3 & 1155.283 & 177.017 & 978.266 & 114 & -75 & -66 & 509 & 245.2 & 237.2 & 228.3 & 2786 & 2924 & 2814 \\
\hline V4 & 1172.263 & 177.017 & 995.246 & -215 & -392 & -356 & 255 & 252.2 & 242.9 & 233.1 & 2870 & 2998 & 2874 \\
\hline V5 & 1172.263 & 177.017 & 995.246 & -219 & -392 & -352 & 256 & 249.3 & 240.0 & 230.2 & 2830 & 2960 & 2840 \\
\hline W1 & 1172.263 & 177.017 & 995.246 & - & -398 & -356 & 249 & - & - & - & - & - & - \\
\hline
\end{tabular}

Table 8 Abscissa of COG, winch rope force, and force in BWB stay: V4 vs. V1

\begin{tabular}{|c|c|c|c|c|c|c|c|c|c|}
\hline \multirow[b]{2}{*}{ Item } & \multicolumn{3}{|c|}{ Abscissa of COG, $x_{\mathrm{COG}}(\mathrm{mm})$} & \multicolumn{3}{|c|}{ Winch rope force, $F_{\mathrm{WR}, \mathrm{DW}}(\mathrm{kN})$} & \multicolumn{3}{|c|}{ BWB stay force, $F_{\mathrm{BWBS}, \mathrm{DW}}(\mathrm{kN})$} \\
\hline & $\begin{array}{c}\mathrm{L}: \alpha_{\mathrm{BWB}}= \\
-19.5^{\circ}\end{array}$ & $\mathrm{H}$ & $\begin{array}{c}\text { Hi: } \alpha_{\mathrm{BWB}}= \\
14.1^{\circ}\end{array}$ & $\begin{array}{c}\mathrm{L}: \alpha_{\mathrm{BWB}}= \\
-19.5^{\circ}\end{array}$ & $\mathrm{H}$ & $\begin{array}{c}\text { Hi: } \alpha_{\mathrm{BWB}}= \\
14.1^{\circ}\end{array}$ & $\begin{array}{c}\mathrm{L}: \alpha_{\mathrm{BWB}}= \\
-19.5^{\circ}\end{array}$ & $\mathrm{H}$ & $\begin{array}{c}\mathrm{Hi}: \alpha_{\mathrm{BWB}}= \\
14.1^{\circ}\end{array}$ \\
\hline $\begin{array}{l}\text { Difference, } \\
\text { "V4-V1" }\end{array}$ & -1044 & -1049 & -1004 & 17.9 & 17.0 & 16.3 & 204 & 204 & 188 \\
\hline
\end{tabular}

\section{Working load analysis}

Load analysis of the vital superstructure parts was carried out according to code DIN 22261-2 (DIN, 2014) for load case (LC) H1.2 (BWE in normal operation) (Figs. 22-24) using our original, inhouse software "EXLOAD".

\section{Stress state of the BWB stay}

BWB stays (Fig. 25a) consist of three hingejoined segments. Each comprises two lamellas made from steel of quality grade $\mathrm{S} 355 \mathrm{~J} 2+\mathrm{N}$, according to code prEN 10025-2 (CEN, 2011). For an eye plate thickness of $50 \mathrm{~mm}$ (Fig. 25b), the yield stress value is $\sigma_{\mathrm{YS}}=335 \mathrm{MPa}$ (CEN, 2011).

The factored tension force per lamella is determined by

$$
\begin{aligned}
Z & =\gamma_{\mathrm{F}} F_{\mathrm{BWBS}, \max } / n_{\mathrm{L}} \\
& =(1.5 \times 4318 / 2) \mathrm{kN}=3238.5 \mathrm{kN},
\end{aligned}
$$

where $\gamma_{\mathrm{F}}=1.5$ is the factor of safety in LC H1.2 (DIN, $2014), F_{\mathrm{BWBS}, \max }=4318 \mathrm{kN}$ is the maximum force in

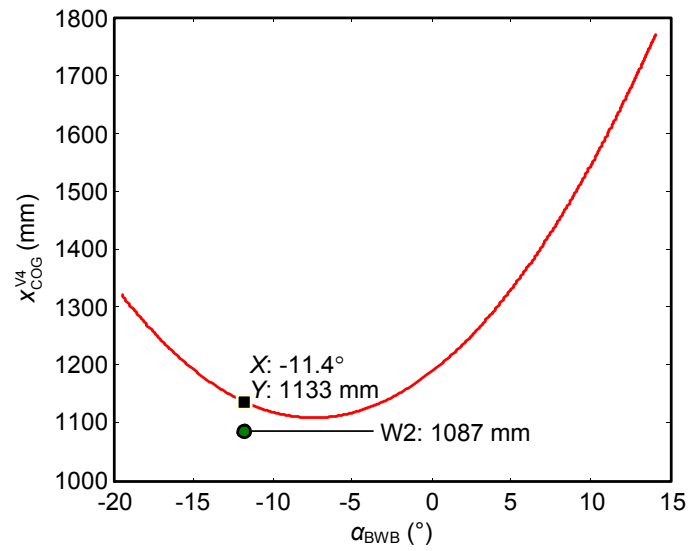

Fig. 21 Abscissa of COG: V4 vs. W2

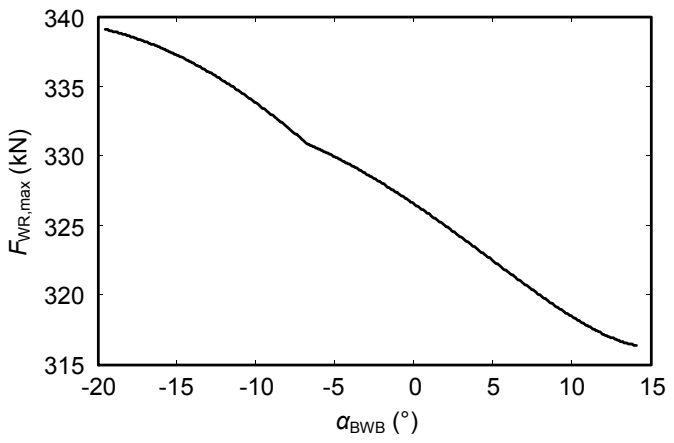

Fig. 22 Maximum winch rope force in LC H1.2 


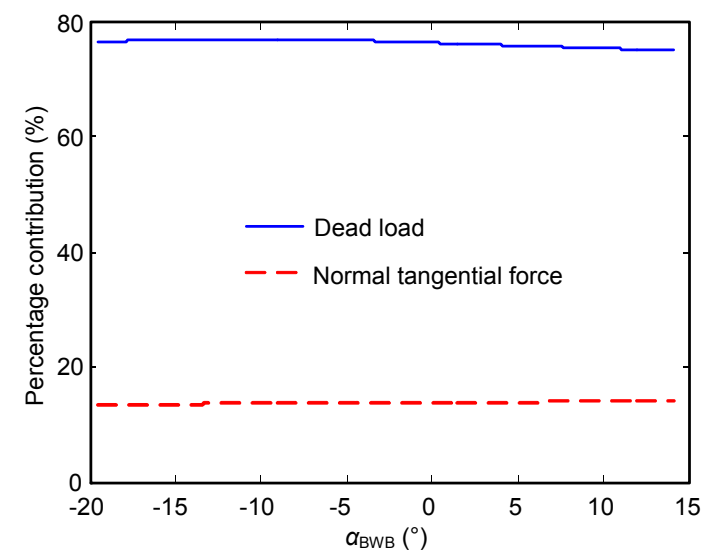

(a)

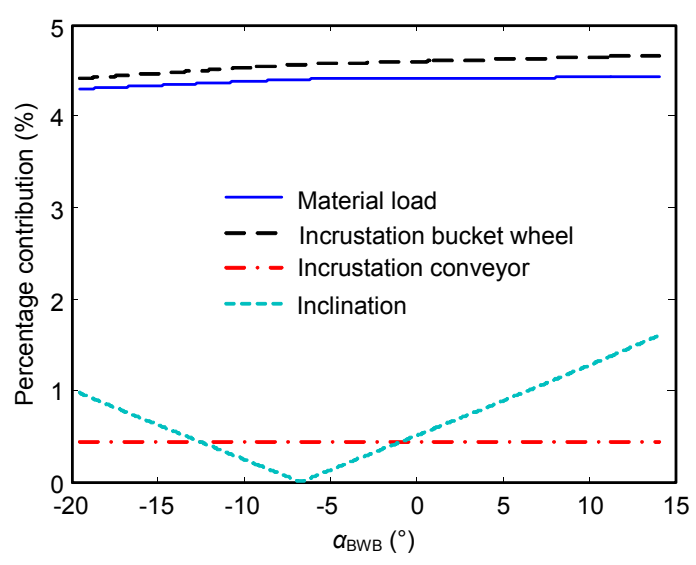

(b)

Fig. 23 Percentage contribution to maximum winch rope force: (a) SuS1 deadweight and normal tangential force; (b) material load, incrustation, and inclination

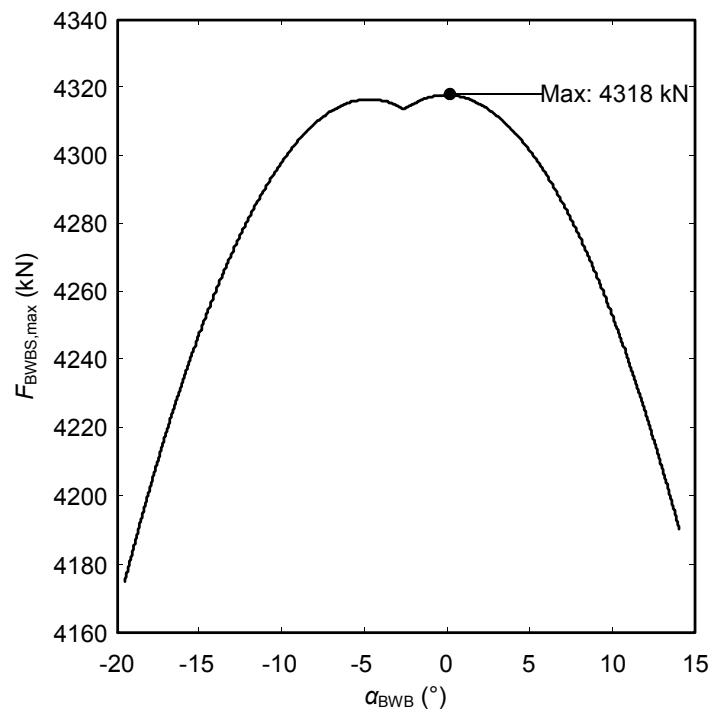

Fig. 24 Maximum force in one BWB stay for LC H1.2

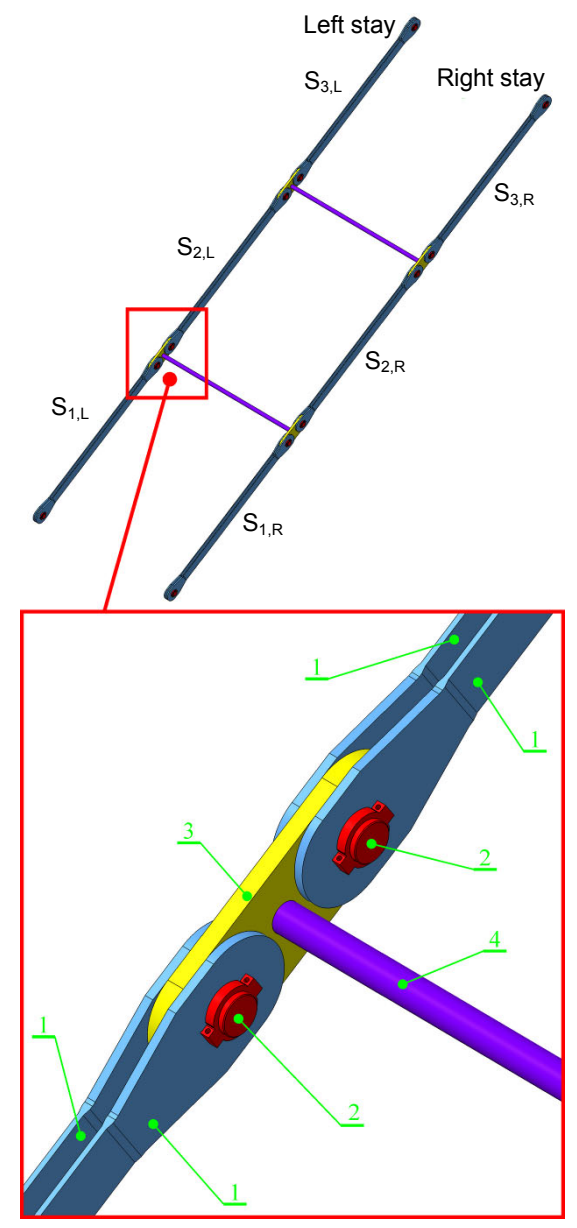

(a)

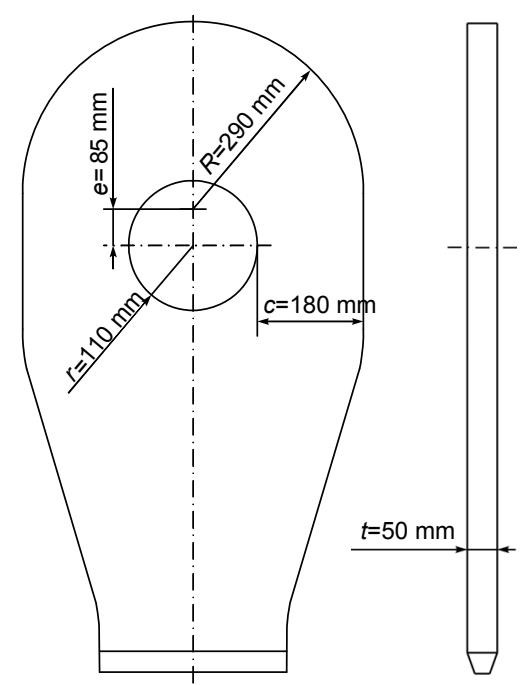

(b)

Fig. 25 BWB stays (a) and geometry of the eye plate (b) 1: lamella; 2: hinge pin; 3: plate; 4: connecting tube; $\mathrm{S}_{1, \mathrm{~L}}$, $\mathrm{S}_{2, \mathrm{~L}}$, and $\mathrm{S}_{3, \mathrm{~L}}$ are the segments of the left stay; $\mathrm{S}_{1, \mathrm{R}}, \mathrm{S}_{2, \mathrm{R}}$, and $\mathrm{S}_{3, \mathrm{R}}$ are the segments of the right stay 
one BWB stay (Fig. 24), and $n_{\mathrm{L}}=2$ is the number of lamellas in each segment of the BWB stays. According to DIN 22261-2 (DIN, 2014), the value of nominal stress caused by the tension force is

$$
\begin{aligned}
\sigma_{\mathrm{n} Z} & =Z /(2 c t)=[3238.5 /(2 \times 18 \times 5)] \mathrm{kN} / \mathrm{cm}^{2} \\
& =18.0 \mathrm{kN} / \mathrm{cm}^{2}=180 \mathrm{MPa},
\end{aligned}
$$

while the value of nominal stress caused by the frictional moment is

$$
\begin{aligned}
\sigma_{\mathrm{n} \mu} & =8 \mu \sigma_{\mathrm{nz} /} /[\pi(1+R / r)] \\
& =\{8 \times 0.33 \times 180 /[\pi(1+29 / 11)]\} \mathrm{MPa} \\
& =41.6 \mathrm{MPa},
\end{aligned}
$$

where $\mu=0.33$ is the frictional coefficient.

The stress state of the lamella was also identified by applying the linear finite element method (FEM), neglecting the influence of the frictional moment. In the critical eye plate cross section, the maximum value of the stress tensor component in the tension force direction is $\sigma_{\max }=496 \mathrm{MPa}$ (Fig. 26).

\section{Discussion 3: load and stress analyses results}

Based on the results presented in Fig. 23a, the dead load has the most influence on the load of the winch rope. In LC H1.2 its minimum percentage contribution to the maximum winch rope force is $74.8 \%$, whilst the maximum contribution of the normal tangential force is $14.1 \%$. The contribution of the other factors (Fig. 23b) is considerably lower: material load, maximum $4.4 \%$; bucket wheel incrustation, maximum $4.7 \%$; conveyor incrustation, maximum $0.4 \%$; inclination, maximum $1.6 \%$. These findings underline the importance of a precise identification of the weight and COG of all parts, as well as of the entire superstructure.

In terms of the nominal stress values in the critical eye plate cross section, Eqs. (11) and (12), and applying the procedure prescribed in DIN 22261-2 (DIN, 2014),

$$
\begin{aligned}
1.4 \sigma_{\mathrm{n}} & =1.4\left(\sigma_{\mathrm{n} Z}+\sigma_{\mathrm{n} \mu}\right)=1.4 \times(180+41.6) \mathrm{MPa} \\
& =310.2 \mathrm{MPa}<\sigma_{\mathrm{YS}}=335 \mathrm{MPa},
\end{aligned}
$$

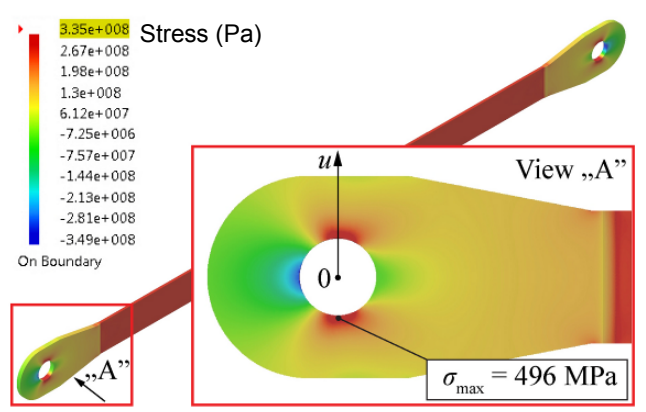

(a)
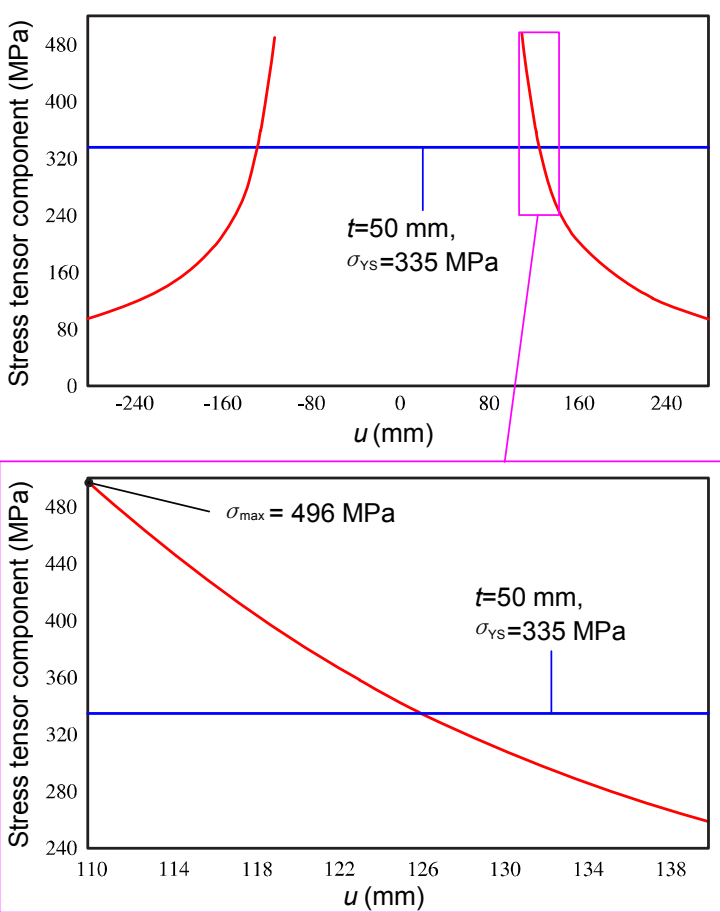

(b)

Fig. 26 Stress tensor component in the direction of the tension force (a) and distribution in the eye plate critical cross section (b)

we conclude that the eye plate satisfies the strength criterion. However, values of the corresponding stress tensor component in the critical eye plate cross section, caused by the factored tension force, are greater than the yield stress value up to a depth of $16 \mathrm{~mm}$, measured from the edge of the hole (Fig. 26b). The value of the geometric stress concentration factor is

$$
\alpha_{\mathrm{K}}=\sigma_{\max } / \sigma_{\mathrm{n} Z}=496 / 180=2.76 .
$$

This value of $\alpha_{\mathrm{K}}$ is in full agreement with values given in the literature. For example, according to values 
presented in Fig. 25b, for

$$
(R-r) /(R+r)=(29-11) /(29+11)=0.45
$$

and

$$
1+e /(R-r)=1+8.5 /(29-11)=1.47
$$

the diagram shown in Fig. 7 of Petersen (1990) gives $\alpha_{K} \approx 2.9$.

Therefore, according to the results of the linear FEM and published data, the geometric stress concentration factor value is about twice as great as the factor 1.4 (Eq. (13)) prescribed by DIN 22261-2 (DIN, 2014). Keeping in mind that tension stresses are dominant in the critical zone, we conclude that the considered eye plate is the weak point in the superstructure and presents a potential danger to its integrity, although it satisfies the strength criterion prescribed by DIN 22261-2 (DIN, 2014).

\section{Conclusions}

The deadweight is a dominant load of the vital parts of a BWE's superstructure, such as stays and winch ropes. However, due to its nature, from the entire set of BWE superstructure's loads, only the deadweight does not have the character of assumption. Therefore, its identification should be conducted with the utmost care during the BWE design, as well as during the first erection.

Based on the presented investigation results we conclude the following:

1. A relatively small difference in the calculated superstructure masses $(1.5 \%)$ leads to a relatively large unfavourable shifting of its COG $(902 \mathrm{~mm}$ towards the bucket wheel), followed by a significant increase in the counterweight mass required for balancing (24t).

2. The 3D model of the superstructure enables a very precise determination of its weight and COG position.

3. By merging the results obtained from the superstructure 3D model and the weighing conducted after the completion of the erection process (first weighing), the distribution of superstructure masses can be fully identified, and a corrected 3D model created. The validity of the model is confirmed by the results of the second weighing, conducted after the correction (increase) of the counterweight mass. The 3D model developed in such a manner provides enough accuracy in determining the superstructure COG in the complete domain of the bucket wheel boom inclination angle, and enables accurate load analysis of the superstructure's vital parts.

4. In LC H1.2 (BWE in normal operation) the minimum percentage contribution of the SuS1 deadweight to the maximum winch rope force is $74.8 \%$.

5 . The procedure for the proof of the eye plates' stress prescribed by code DIN 22261-2 (DIN, 2014) gives results, which are not on the side of safety, as demonstrated by the example of the bucket wheel boom stay's eye plate.

\section{References}

Bartelmus, W., 2006. Condition Monitoring of Open Cast Mining Machinery. Wroclaw University Press, Wroclaw, Poland.

Bartelmus, W., Zimorz, R., 2009. A new feature for monitoring the condition of gearboxes in non-stationary operating conditions. Mechanical Systems and Signal Processing, 23(5):1528-1534. http://dx.doi.org/10.1016/j.ymssp.2009.01.014

Bošnjak, S., Zrnić, N., 2012. Dynamics, failures, redesigning and environmentally friendly technologies in surface mining systems. Archives of Civil and Mechanical Engineering, 12(3):348-359. http://dx.doi.org/10.1016/j.acme.2012.06.009

Bošnjak, S., Oguamanam, D., Zrnić, N., 2006. On the dynamic modeling of bucket wheel excavators. FME Transactions, 34(4):221-226.

Bošnjak, S., Zrnić, N., Simonović, A., et al., 2009a. Failure analysis of the end eye connection of the bucket wheel excavator portal tie-rod support. Engineering Failure Analysis, 16(3):740-750. http://dx.doi.org/10.1016/j.engfailanal.2008.06.006

Bošnjak, S., Petković, Z., Zrnić, N., et al., 2009b. Cracks, repair and reconstruction of bucket wheel excavator slewing platform. Engineering Failure Analysis, 16(5): 1631-1642. http://dx.doi.org/10.1016/j.engfailanal.2008.11.009

Bošnjak, S., Zrnić, N., Gašić, V., et al., 2012. External load variability of multibucket machines for mechanization. Advanced Materials Research, 422:678-683. http://dx.doi.org/10.4028/www.scientific.net/amr.422.678

CEN (European Committee for Standardisation), 2011. Hot Rolled Products of Structural Steels-Part 2: Technical Delivery Conditions for Non-alloy Structural Steels, prEN 10025-2:2011. CEN, Brussels, Belgium.

Czmochowski, J., 2008. Identyfikacja modeli modalnych maszyn urabiających $\mathrm{w}$ górnictwie węgla brunatnego. 
Oficyna Wydawnicza Politechniki Wrocławskiej, Wroclaw, Poland (in Polish).

DIN (Deutsches Institut für Normung), 2014. Bagger, Absetzer und Zusatzgeräte in BraunkohlentagebauenTeil 2: Berechnungsgrundlagen, DIN 22261-2:2014. DIN, Germany (in German).

Dudek, D., Frydman, S., Huss, W., et al., 2011. The L35GSM cast steel-possibilities of structure and properties shaping at the example of crawler links. Archives of Civil and Mechanical Engineering, 11(1):19-32. http://dx.doi.org/10.1016/S1644-9665(12)60171-X

Durst, W., Vogt, W., 1988. Bucket Wheel Excavator. Trans Tech Publications, Clausthal-Zellerfeld, Germany.

Gottvald, J., 2010. The calculation and measurement of the natural frequencies of the bucket wheel excavator SchRs 1320/4x30. Transport, 25(3):269-277. http://dx.doi.org/10.3846/transport.2010.33

Gottvald, J., Kala, Z., 2012. Sensitivity analysis of tangential digging forces of the bucket wheel excavator SchRs 1320 for different terraces. Journal of Civil Engineering and Management, 18(5):609-620. http://dx.doi.org/10.3846/13923730.2012.719836

Nan, N., Kovacs, I., Popescu, F., 2008. Balance control by weighting and tensiometric measurements of bucket wheel excavators. WSEAS Transactions on Systems and Control, 3(11):927-938.

Petersen, C., 1990. Stahlbau: Grundlagen der Berechnung und Baulichen Ausbildung von Stahlbauten, 2nd Edition. Vieweg, Braunschweig, Germany.

Rişteiu, M., Ileană, I., Duma, S., 2006. New approaches in heavy duties industrial processes monitoring by using smart sensors. Acta Universitatis Apulensis, 12:80-92.

Rusiński, E., Czmochowski, J., Iluk, A., et al., 2010a. An analysis of the causes of a BWE counterweight boom support fracture. Engineering Failure Analysis, 17(1): 179-191. http://dx.doi.org/10.1016/j.engfailanal.2009.06.001

Rusiński, E., Moczko, P., Kaczyński, P., 2010b. Structural modifications of excavator's bucket wheel by the use of numerical methods. Solid State Phenomena, 165:330335.

http://dx.doi.org/10.4028/www.scientific.net/ssp.165.330

Rusiński, E., Dragan, S., Moczko, P., et al., 2012. Implementation of experimental method of determining modal characteristics of surface mining machinery in the modernization of the excavating unit. Archives of Civil and
Mechanical Engineering, 12(4):471-476.

http://dx.doi.org/10.1016/j.acme.2012.07.002

Savković, M., Gašić, M., Arsić, M., et al., 2011. Analysis of the axle fracture of the bucket wheel excavator. Engineering Failure Analysis, 18(1):433-441. http://dx.doi.org/10.1016/j.engfailanal.2010.09.031

Yin, Y., Grondin, G.Y., Obaia, K.H., et al., 2007. Fatigue life prediction of heavy mining equipment. Part 1: Fatigue load assessment and crack growth rate tests. Journal of Constructional Steel Research, 63(11):1494-1505. http://dx.doi.org/10.1016/j.jcsr.2007.01.008

Yin, Y., Grondin, G.Y., Obaia, K.H., et al., 2008. Fatigue life prediction of heavy mining equipment. Part 2: Behaviour of corner crack in steel welded box section and remaining fatigue life determination. Journal of Constructional Steel Research, 64(1):62-71.

http://dx.doi.org/10.1016/j.jcsr.2007.04.003

\section{中文概要}

题 目: 斗轮挖掘机回转支承上部结构中关键部件的静 态稳定性基本参数、负载和强度研究

目的: 斗轮挖掘机回转支承上部结构的重量和重心位 置不仅在设计过程中非常重要，在斗轮挖掘机 组装完成后和运转时同样重要。本文旨在研究 各参数对重心位置的影响。

方 法: 1. 分析比较由数值模拟和实验得到的静态稳定 性基本参数; 2. 构建上部结构的 $3 \mathrm{D}$ 模型（图 1 3），并根据斗轮挖掘机组装完成后的重量分 布对模型进行质量修正; 3. 对上部结构进行负 载和应力分析。

结 论: 1. 上部结构一个较小的质量变化 (1.5\%) 会导 致重心位置一个较大的变化 $(902 \mathrm{~mm})$, 从而不 得不明显增加配重的重量（24t）来保持平衡;

2. 构建的 3D 模型可以得到精确的上部结构重量 分布和重心位置; 3. 由 DIN 22261-2 标准规定的 眼板应力被证明并不安全。

关键词: 斗轮挖掘机; 回转支承上部结构; 静态稳定性 参数; 负载; 强度 